Published in Fungal Diversity (2013) 59:33-44

DOI: 10.1007/s13225-012-0180-y

(C) 2012 Mushroom Research Foundation

Published by Springer

\title{
Myxomycetes from Papua New Guinea and New Caledonia
}

Henrik Kylin $^{1 *}$, David W. Mitchell ${ }^{2}$, El-Hacène Seraoui ${ }^{3}$, Bart Buyck ${ }^{4}$

${ }^{1}$ Department of Water and Environmental Studies, Linköping University, SE-58183

Linköping Sweden

${ }^{2}$ Walton Cottage, Upper Hartfield, East Sussex, TN7 4AN, England

${ }^{3}$ 11, rue Louis Armand, F-74100 Ambilly, France

${ }^{4}$ Muséum national d'Histoire naturelle, Department of Systematics and Evolution CP39, UMR7205, F-75005 Paris, France

*Corresponding author: Henrik.Kylin@liu.se, Tel +46 70683 3619, Fax +4613133630

\begin{abstract}
We present a compilation of all myxomycetes recorded in Papua New Guinea (PNG) and New Caledonia (NC). Specimens were collected during field trips in September 1983 January 1984 to both territories and in August 1991, October 2007, and April 2009 to NC. Bark and dung samples for moist chamber cultures were collected during the field trips in September 1983 - January 1984 (PNG and NC) and in August 1991 and October 2007 (NC). In addition, information from previous publications and unpublished specimens in the herbarium at the Plant Protection Instituted in Port Moresby, PNG, are included. A total of 180 species are reported. Of the 63 species from PNG 51 are new to the country, and 123 of the 149 species from NC are new to the territory.
\end{abstract}

Key words: Mycetozoa, myxomycota, amoebozoa, slime moulds, Southwest Pacific.

\section{Introduction}

Myxomycetes, plasmodial or syncytial slime moulds, is a group of microscopic organisms with an amoeba-like trophic stage and reproductive structures with spores. Although myxomycetes occur globally in most types of terrestrial environments, their know distributions largely reflect where the few specialists studying the group have worked. This is the case, e.g., for the islands in the southwest Pacific Ocean from which, with the exception of New Zealand (Mitchell 1992; Stephenson 2003; Stephenson et al. 2009) and Fiji and Western Samoa (Kylin and Mitchell 1987; Macbride 1926), there are only a few publications each 
recording a single (Berkeley 1842; Farr 1979) or a handful (Huguenin and Kohler 1969; Lister 1922; Schumann and Lauterbach 1901; Shaw 1984; Sydow and Sydow 1916) of species.

In this paper we report on collections made during four field trips to Papua New Guinea (PNG) and New Caledonia (NC). We also compile data from other sources (Berkeley 1842; Farr 1979; Huguenin and Kohler 1969; Lister 1922; Schumann and Lauterbach 1901; Shaw 1984; Sydow and Sydow 1916; UARK 2012) and re-examine specimens kept in the herbarium of the Plant Protection Institute, Port Moresby, PNG. A total of 180 species are reported. Of the 63 species reported from PNG 51 are recorded for the first time, and of the 149 species reported from NC 123 are recorded for the first time. In this treatment we include the genus Ceratiomyxa. Although there are discussions on the phylogenetic status of this taxon, it has traditionally been treated among the Myxomycetes and was recently suggested to be a deeply diverging sister to these (Fiore-Donno et al. 2010).

\section{Materials and methods}

New Guinea is the largest and highest tropical island in the world with an estimated 8\% of the world's species out of which 70\% or more are endemic (Allison 2009). The island is set in the interface between the northward-moving Australian plate and the west-northwest-moving Pacific plate with much tectonic activity along the northern rim of the island and Palaeozoic or Precambrian basement in the south (Davies 2009). Fieldwork in PNG was carried out by the first author in October 1983 in the Lae, Boana, and Bulolo Districts of the Morobe Province and in the National Botanical Gardens in Port Moresby. In the Morobe province the weather was characterized by rainfall each night between ca. 22:00 and 24:00 hours, while in Port Moresby there was no rainfall at the time of the fieldwork. Temperatures in the lowland locations were around $30{ }^{\circ} \mathrm{C}$ during daytime, dropping to $25^{\circ} \mathrm{C}$ after the nightly rain. In the highland locations daytime temperatures were around $25^{\circ} \mathrm{C}$ dropping to $10{ }^{\circ} \mathrm{C}$ at night. For more information on climatic and geological conditions se Allison (2009) and Davies (2009).

New Caledonia is situated on the Tropic of Capricorn with a subtropical climate and, despite its relatively small size, is recognized as a biodiversity hotspot with extremely high species richness and rate of endemism (Murienne 2009). The main island, Grande Terre, and Kunié (Isle of Pines) are composed of a complex mixture of metamorphic, igneous, and sedimentary rocks with both continental and oceanic affinities, while the Loyalty Islands are uplifted reefs (Rawling 2009). The dominating feature in the southeast of Grand Terre is the world's second largest mass of ultrabasic rock (Rawling 2009). Most of the fieldwork was carried out from October to early January, which is the transition from the dry to wet season with occasional rains and daytime temperatures $\sim 24{ }^{\circ} \mathrm{C}$ dropping to $\sim 18{ }^{\circ} \mathrm{C}$ at night. For more information on climatic and geological conditions se Murienne (2009) and Rawling (2009).

Field collections consisted of mature fructifications as well as bark, ground and aerial litter, herbivore dung, and soil for moist chamber cultures. Bark, litter, and dung samples were processed in moist chamber cultures for corticolous and fimicolous myxomycetes (Mitchell 1980). 
Field collections were done in PNG in October 1983 and in NC in October 1983-January 1984, October 2007, and April 2009. The collections in 1983-1984 were done by H. Kylin and sent continuously to D. W. Mitchell for determination. The collections in 2007 and 2009 were made by E.-H. Seraoui and B. Buyck, respectively. In addition, a few specimens, as well as soil, bark, and dung samples were collected in August 1991 in NC by F. Ljungqvist and processed by H. Kylin.

For the case of brevity the locations visited by the authors of this paper are numbered. In the list below the locations are given with name, approximate latitude and longitude and elevation, and brief comments on the vegetation.

\section{Papua New Guinea}

1. Lae, $6.72^{\circ} \mathrm{S}, 146.99^{\circ} \mathrm{E}$, coastal lowland, Botanical Gardens of the Forest Research Institute

2. Oomsis, $6.72^{\circ} \mathrm{S}, 146.07^{\circ} \mathrm{E}, 200-400 \mathrm{~m}$, primary and secondary forest

3. Wampit, $6.73^{\circ} \mathrm{S}, 146.67^{\circ} \mathrm{E}, 100-300 \mathrm{~m}$, primary and secondary forest

4. Moimbling, $6.45^{\circ} \mathrm{S}, 146.82^{\circ} \mathrm{E}, 500 \mathrm{~m}$, grassland with cycads and forest patches

5. Bulolo, $7.21^{\circ} \mathrm{S}, 146.63^{\circ} \mathrm{E}, 700 \mathrm{~m}$, College of Forestry arboretum

6. Wau, $7.34^{\circ} \mathrm{S}, 146.73^{\circ} \mathrm{E}, 1100 \mathrm{~m}$, rain forest

7. Mt Kaindi, $7.35^{\circ} \mathrm{S}, 146.68{ }^{\circ} \mathrm{E}, 2100 \mathrm{~m}$, cloud forest

8. Mt Susu, $7.05^{\circ} \mathrm{S}, 146.43^{\circ} \mathrm{E}, 1400 \mathrm{~m}$, Araucaria plantation with rich understory

9. Mankei, $7.07^{\circ} \mathrm{S}, 146.25^{\circ} \mathrm{E}, 1600 \mathrm{~m}$, secondary growth in a clear-felled Araucaria plantation

10. Port Moresby, $9.41^{\circ} \mathrm{S}, 147.17^{\circ} \mathrm{E}$, coastal lowland, National Capital Botanical Garden

\section{New Caledonia}

\section{Province Loyauté}

11. Lifou Island, Gaïcha, $20.93^{\circ} \mathrm{S}, 167.17^{\circ} \mathrm{E}$, coastal lowland, maquis

Province Sud, Kunié (Isle of Pines)

12. Grotte Reine Hortense, $22.58^{\circ} \mathrm{S}, 167.47^{\circ} \mathrm{E}, 30 \mathrm{~m}$, humid primary forest

13. Baie d'Oro-Baie d’Upi, $22.98{ }^{\circ} \mathrm{S}, 167.86^{\circ} \mathrm{E}$, lowland coastal, humid primary forest with palms

14. Kuto-Airport road, $22.98^{\circ} \mathrm{S}, 167.75^{\circ} \mathrm{E}, 40 \mathrm{~m}$, grassland with bushes

\section{Province Sud, Grand Terre}

15. Port Boisé, $22.35^{\circ} \mathrm{S}, 166.97^{\circ} \mathrm{E}$, coastal lowland, humid primary forest

16. Monts Ongoné, $22.33^{\circ} \mathrm{S}, 166.91^{\circ} \mathrm{E}, 100 \mathrm{~m}$, coastal, humid primary forest

17. Plain de Lac, $22.27^{\circ} \mathrm{S}, 166.88^{\circ} \mathrm{E}, 200-300 \mathrm{~m}$, maquis

18. Nouméa, $22.27^{\circ} \mathrm{S}, 166.46^{\circ} \mathrm{E}$, lowland, parks and gardens

19. Pic du Pin, $22.25^{\circ} \mathrm{S}, 166.88^{\circ} \mathrm{E}, 450 \mathrm{~m}$, maquis and savannah with planted Pinus caribaea Morelet 
20. Col de Mouirange, $22.23^{\circ} \mathrm{S}, 166.65^{\circ} \mathrm{E}$, maquis and savannah

21. Chute de la Madeleine, $22.22^{\circ} \mathrm{S}, 166.85^{\circ} \mathrm{E}, 250$, maquis

22. Valle de la Thi, $22.21^{\circ} \mathrm{S}, 166.54^{\circ} \mathrm{E}, 50-200 \mathrm{~m}$, humid primary forest

23. Mont Koghi, $22.17^{\circ} \mathrm{S}, 166.50^{\circ} \mathrm{E}, 600-800 \mathrm{~m}$, humid primary forest

24. Doumbea, $22.15166 .43,100 \mathrm{~m}$, sclerophyll forest

25. Montagne de Source, $22.12^{\circ} \mathrm{S}, 166.60^{\circ} \mathrm{E}, 800 \mathrm{~m}$, humid primary forest

26. Rivière Bleue, $22.10^{\circ} \mathrm{S}, 166.67^{\circ} \mathrm{E}, 200-300 \mathrm{~m}$, humid primary forest

27. Mont Mou, $22.05^{\circ} \mathrm{S}, 166.33^{\circ} \mathrm{E}, 700-100 \mathrm{~m}$, humid primary forest

28. Mont Dzumac, $22.05^{\circ} \mathrm{S}, 166.47^{\circ} \mathrm{E}, 700 \mathrm{~m}$, interspaced savannah, maquis and humid primary forest

29. Boulouparis, Quitchambo, Parc à écrevisses, $21.80^{\circ} \mathrm{S}, 166.00^{\circ} \mathrm{E}, 100 \mathrm{~m}$, maquis

30. Mont Do, $21.75^{\circ} \mathrm{S}, 166.00{ }^{\circ} \mathrm{E}, 400-600 \mathrm{~m}$, humid primary forest

31. Dothio, $21.66^{\circ} \mathrm{S}, 166.18^{\circ} \mathrm{E}, 300-400 \mathrm{~m}$, maquis and secondary forest

32. Plateau de Dogny, $21.62^{\circ} \mathrm{S}, 165.88^{\circ} \mathrm{E}, 300-1000 \mathrm{~m}$, humid primary forest with grassland and bog on top of the plateau

33. Plage de Ouroué, $21.61^{\circ} \mathrm{S}, 166.23^{\circ} \mathrm{E}$, coastal lowland, municipal beach park

34. Col the Petchecara, $21.58{ }^{\circ} \mathrm{S}, 166.08{ }^{\circ} \mathrm{E}, 400-600 \mathrm{~m}$, humid primary forest

35. Cascade de Ciu to Koindé, $21.57^{\circ} \mathrm{S}, 165.83^{\circ} \mathrm{E}, 200-400 \mathrm{~m}$, interspaced pastureland and humid primary and secondary forest

36. Katrikoin to Mè-Ori, $21.52^{\circ} \mathrm{S}, 165.67^{\circ} \mathrm{E}, 300-600 \mathrm{~m}$, interspaced pastureland and humid primary forest

Province Nord, Grand Terre

37. Prokomeo, $21.50^{\circ} \mathrm{S}, 165.83^{\circ} \mathrm{E}, 400-500 \mathrm{~m}$, humid primary and secondary forest

38. Pont Tamanou, $20.93^{\circ} \mathrm{S}, 165.05^{\circ} \mathrm{E}, 250 \mathrm{~m}$, plantation of Pinus caribaea Morelet

39. Hienghène, $20.70^{\circ} \mathrm{S}, 165.00^{\circ} \mathrm{E}$, coastal lowland, coconut plantation

40. Mont Panié, $20.60^{\circ} \mathrm{S}, 164.78^{\circ} \mathrm{E}, 100-1600 \mathrm{~m}$, humid primary forest

41. Mandjelia, $20.40^{\circ} \mathrm{S}, 164.53^{\circ} \mathrm{E}, 400-700 \mathrm{~m}$, humid primary and secondary forest

In the list of species the collection locations are given with their numbers in parentheses following the specimen number. These numbers have also, if applicable, been used to specify locations of samples collected by Huguenin and Kohler (1969), but sample collected at other locations than in the above list are given as name (in parentheses). Lister (1922) gives no specific information on locations except that all samples were collected "in the high forests within thirty miles of Nouméa”.

\section{List of species}

The nomenclature follows “Nomen Eumycetozoa” (Lado 2005-2012); specimens reported previously, e.g, by Lister (1922) and Huguenin and Kohler (1969) are here included under the name given priority according to this reference.

Specimen codes JHK - Henrik Kylin; EHS - El-Hacène Seraoui; PNG - specimens from the herbarium at the Plant Protection Institute, Port Moresby, PNG; NC - specimens collected by the “Office de la Recherche Scientifique et Technique d'Outre-Mer” in Nouméa (Huguenin 
and Kohler 1969); MNHN - specimens collected by Bart Buyck and kept at the "Muséum national d'Histoire naturelle”, Paris. Specimens JHK and EHS are kept in our private herbaria, but will successively be transferred to appropriate museum collections. MC after the specimen code signifies developed in moist chamber.

Arcyria cinerea (Bull.) Pers.

PNG: JHK24a (1), JHK66 (3), JHK75c (4), JHK84 (4), JHK108 (6), JHK111b (6), JHK126 (8), on decaying wood. JHK82 (4), JHK746MC (1), JHK772MC (1), on bark. JHK917aMC (8), on Araucaria bark. New to PNG.

NC: EHS3368 (26), on decaying wood. EHS3422 MC on freahly cut wood. NC68025 (22), on dead wood. MNHN09.326 (18), MNHN09.333 (18). Also reported by Lister (1922).

Arcyria denudata (L.) Wettst.

PNG: JHK24b (1), JHK115 (6), JHK934 (1), JHK1023 (4), on decaying wood. Historical records (as A. punicea Pers.) from "Kaiser Wilhelm Land” in Schumann and Lauterbach (1901), and (as A. denudata Sheldon) in Sydow and Sydow (1916).

NC: JHK255 (32), JHK309 (35), JHK339 (36), JHK374 (32), JHK417 (15), JHK418 (15), JHK419 (15), JHK420a (15), JHK426 (22), JHK427 (28), JHK434 (27), EHS3387 (39), EHS3391 (12), EHS3362 (23), NC68026 (22), NC67026 (Col de la Pirogue), on decaying wood. MNHN09.327 (18). Lister (1922) reports four specimens (as A. denudata (L.)

Sheldon). Huguenin and Kohler (1969) state that this species is common in NC, and later collections confirm this.

Arcyria cf. glauca Lister

PNG: JHK917bMC (8), on Araucaria bark. New to PNG.

Determination confirmed by N.E. Nannenga-Bremekamp. Another moist chamber of the same bark sample yielded typical $A$. cinerea. This fructification is clearly different in much shorter stalks, absence of fused stalks, and clearly green colour. However, the spores are larger than suggested in the literature as typical for A. glauca (8.5-9.5 $\mu \mathrm{m}$ instead of $7 \mu \mathrm{m})$, but as the species has been rarely reported globally, this may be within the natural range of spore size for the species.

Arcyria cf. globosa Schwein.

NC: JHK757MC (31), on bark. New to NC.

Specimen somewhat mouldy with partially collapsed spores making absolute determination difficult.

Arcyria incarnata (Pers. ex J. F. Gmel.) Pers.

PNG: JHK116a (6), on the wooden frame of a bird cage. JHK709MC (1), on bark. New to PNG.

NC: JHK396 (15), JHK397 (15), on decaying wood. New to NC.

Arcyria minuta Buchet

NC: NC67084 (la Crouen). Reported as A. carnea Lister.

Arcyria nigella Emoto

NC: JHK766MC (21), on Neocallitropsis bark. New to NC. 
Arcyria obvelata (Oeder) Onsberg

PNG: JHK889 (1), on decaying wood. New to PNG.

NC: JHK908 (41), on decaying sawdust. New to NC.

Arcyria pomiformis (Leers) Rostaf.

PNG: JHK727MC (8), on Araucaria bark. New to PNG.

Badhamia affinis Rostaf.

NC: JHK1493MC (24), on bark. New to NC.

Badhamia foliicola Lister

NC: NC66179. "Frequent in grey [dead?] patches of the lawn in the stadium” (Huguenin and Kohler 1969).

Badhamia nitens Berk.

PNG: JHK724MC (10), on bark. New to PNG.

Badhamia cf. ovispora Racib.

NC: JHK966aMC (21), on Casuarina bark. New to NC.

Determination by N. E. Nannenga-Bremekamp. Spores ellipsoid, but less difference between long and short diagonal than given in literature.

Badhamia utricularis (Bull) Berk.

NC: JHK1454gMC (18), on tortoise dung. New to NC.

Badhamiopsis ainoae (Yamash.) T. E. Brooks \& H. W. Keller

NC: JHK1477MC (17), on bark. New to NC.

Calomyxa metallica (Berk.) Nieuwl.

NC: JHK878MC (36), on bark from Olea paniculata R. Br. New to NC.

Ceratiomyxa fruticulosa (O. F. Müll.) T. Macbr.

PNG: JHK47s (2), JHK60s (3), JHK95as (7), JHK114s (6), JHK122s (8), on decaying wood. JHK778dMC (6), on Eucalyptus bark. New to PNG.

NC: JHK158 (28), JHK172 (32), JHK183 (32), JHK200s (28), JHK204 (23), JHK262 (32), JHK289 (31); JHK329 (36), JHK425 (22), and four EHS specimens without number from (11), (23), (26), and (39), on decaying wood. NC67005 (18), as C. fruticulosa var. flexuosa (Lister) G. Lister on the decaying trunk of Cocos nucifera L. NC67126 (22), as C. fruticulosa var. porioides (Alb. \& Schwein.) G. Lister on decaying wood.

Common and widespread on decaying wood both in PNG and NC. Most PNG specimens had a morphology resembling $C$. fruticulosa var. descendens Emoto.

Ceratiomyxa morchella A. L. Welden

PNG: One collection from Bulolo (UARK 2012)

NC: JHK412s (26), on decaying wood. New to NC.

Ceratiomyxa sphaerosperma Boedjin

NC: JHK236s (32), on decaying wood. New to NC.

Clastoderma debaryanum A. Blytt

PNG: JHK700MC (1), JHK877aMC (6), JHK881MC(8) on bark. New to PNG. 
NC: JHK424b (16), on decaying wood. EHS3423MC (12), on bark. JHK901MC (18), JHK911MC (26), JHK1460aMC (24), on bark. New to NC.

Common in moist chamber cultures and also collected in the field. Many of the specimens from moist chamber cultures exhibited prominent netting on the peridial platelets.

Clastoderma pachypus Nann.-Bremek.

NC: JHK689hMC (36), on bark from Olea paniculata R. Br. New to NC.

Collaria arcyrionema (Rostaf.) Nann.-Bremek. ex Lado

PNG: JHK51b (2), on decaying wood. New to PNG.

NC: JHK320 (36), JHK322 (36), JHK324 (36), JHK333 (36), JHK350 (36), JHK353c (36), EHS3365 (23), NC67042 (as Lamproderma arcyrionema Rostaf. from Col d’Amien), on decaying wood. JHK747MC (37), on Meterosideros bark.

Colloderma robustum Meylan

NC: JHK1454aMC (18), on tortoise dung. New to NC.

Comatricha elegans (Racib.) G. Lister

PNG: JHK93 (7), on a freshly felled Nothofagus. JHK705MC (1), on Pinus merkusii

Junghuhn \& de Vriese bark. New to PNG.

NC: JHK340 (36), on decaying wood. New to NC.

Comatricha laxa Rostaf.

NC: JHK389 (37), on decaying wood. New to NC.

Comatricha nigra (Pers. ex J. F. Gmel.) J. Schröt.

PNG: JHK92 (7), on decaying wood. New to PNG.

NC: JHK346 (36), JHK351 (36), JHK432 (27), on decaying wood. New to NC.

Comatricha cf. parvispora Dhillon \& Nann.-Bremek.

NC: JHK439 (26), on decaying wood. New to NC.

Specimen somewhat mouldy with partially collapsed spores making absolute determination difficult.

Comatricha pulchella (C. Bab.) Rostaf.

NC: JHK364 (18), on decaying wood. New to NC.

Comatricha tenerrima (M. A. Curtis) G. Lister

PNG: JHK72 (4), JHK75a (4), on decaying wood. New to PNG.

NC: JHK361 (18), on decaying wood. New to NC.

Craterium leucocephalum (Pers. ex J. F. Gmel.) Ditmar

PNG: JHK58 (3), on decaying leaves. JHK67 (3), on living Zingiberaceae. New to PNG.

Craterium minutum (Leers) Fr.

NC: JHK900 (24), on decaying wood. New to NC.

Craterium paraguayense (Speg.) G. Lister

NC: JHK833aMC (40), on litter from Parasitaxus usta (Vieill.) de Laub. New to NC.

Cribraria atrofusca G. W. Martin \& Lovejoy

NC: JHK170 (28), on decaying wood. New to NC. 
Cribraria aurantiaca Schrad.

PNG: JHK23s (1), on a termite nest. New to PNG.

Cribraria cancellata (Batsch) Nann.-Bremek.

PNG: JHK53 (2), on a dead tree. JHK110 (6), JHK116b (6), on decaying wood. New to PNG.

Cribraria confusa Nann.-Bremek. \& Y. Yamam.

NC: JHK303c (35), on decaying wood. New to NC.

Cribraria intricata Schrad.

NC: JHK353b (36), NC67010 (17), on decaying wood. MNHN09329 (19). N. E. NannengaBremekamp determined JHK353b to $C$. dictydioides Cooke \& Balf.f., now regarded as synonym of $C$. intricata Schrad.

Cribraria cf. irregularis $\mathrm{Yu} \mathrm{Li}$

PNG: JHK862bMC (9), on bark from a partially dead Araucaria. New to PNG.

Four sporocarps; first regarded as poorly developed and indeterminable, but they fit the description of Cribraria irregularis well except that the spores are larger, 7-8 $\mu \mathrm{m}$ in diameter.

Cribraria microcarpa (Schrad.) Pers.

PNG: JHK48 (2), on decaying wood. JHK118 (6), on a decaying banana frond. JHK804cMC (1), JHK816MC (8), on bark. New to PNG.

NC: JHK199 (28), JHK299 (35), JHK326b (36), JHK327 (36), JHK328c (36), JHK352 (36), JHK358b (36), JHK363c (18), JHK378 (32), JHK382s (32), JHK384 (32), JHK385b (32), JHK420b (15), JHK424a (16), JHK433 (27), JHK441 (25), JHK442 (25), decaying wood. JHK823MC (18), JHK845MC (25), JHK861aMC (41), on bark. New to NC.

Very common; this was the myxomycete species most frequently encountered in the field by $\mathrm{H}$. Kylin both in PNG and the humid forests of NC, and also humid forests elsewhere in the South Pacific (Kylin and Mitchell 1987).

Cribraria minutissima Schwein.

NC: JHK301 (35), on a decaying palm frond. JHK302 (35), on decaying wood. New to NC.

Cribraria rufa (Roth) Rostaf.

PNG: JHK707MC (1), on bark from Callitris colummelaris F. Müll. New to PNG.

NC: NC67004 (18), on decaying wood. JHK689dMC (36), on bark from Olea paniculata R.

$\mathrm{Br}$.

Cribraria splendens (Schrad.) Pers.

NC: JHK266 (32), on decaying wood. New to NC.

Cribraria violacea Rex

PNG: JHK777MC (6), on bark from dead Eucalyptus. New to PNG.

NC: JHK348c (36), on decaying wood. New to NC.

Diachea leucopodia (Bull.) Rostaf.

NC: NC67008 (18), on dry, dead leaves and twigs.

Diachea radiata G. Lister \& Petch

NC: JHK1479c (26), on decaying plant litter. New to NC. 
Diachea splendens Peck

PNG: JHK861cMC (1), on termite nest material. New to PNG.

Dianema corticatum Lister

NC: JHK931MC (24), on bark. New to NC.

Dictydiaethalium dictyosporum Nann.-Bremek.

NC: EHS3379 (29). On decaying wood. New to NC.

Dictydiaethalium plumbeum (Schumach.) Rostaf.

NC: JHK359 (36), EHS3410 (11), on decaying wood. Also reported by Lister (1922) as D. plumbeum var. enthoxanthum (Berk.) G. Lister

Diderma cf. chondrioderma (de Bary \& Rostaf.) G. Lister

NC: JHK692MC (36), on bark from Olea paniculata R. Br. New to NC.

Diderma cf. radiatum (L.) Morgan

NC: JHK184 (32), on decaying wood. New to NC.

Determination N.E. Nannenga-Bremekamp. Collected on the sun exposed side of a decaying log that on the shaded side yielded $D$. umbilicatum. Most authors discussing the distinction between these two species seem to agree that they are closely related (e.g., Buyck 1982;

Nannenga-Bremekamp 1991). The field observations of $\mathrm{H}$. Kylin open the question whether the distinction between the two species is real or phenotypic differences caused by the fruiting conditions, in this case on the different sides of the log with different insolation and humidity.

Diderma rugosum (Rex) T. Macbr.

PNG: JHK64 (3), on decaying wood. New to PNG.

Diderma umbilicatum Pers.

NC: JHK185 (32), on decaying wood. New to NC.

Determination N.E. Nannenga-Bremekamp. See comment under D. cf. radiatum.

Didymium iridis (Ditmar) Fr.

NC: EHS3408 (11), on decaying wood. EHS3395 (12), on coconut palm fronds. New to NC.

Didymium nigripes (Link) Fr.

PNG: JHK71 (4), on decaying leaves. New to PNG.

NC: JHK367 (18), JHK368 (18), EHS3407 (11), on decaying wood. Also reported (as D.

nigripes Fries) by Lister (1922).

Didymium serpula Fr.

NC: JHK883 (40), on litter from Parasitaxus usta (Vieill.) de Laub. New to NC.

Didymium squamulosum (Alb. \& Schwein.) Fr.

NC: EHS3409 (11), on decaying wood. New to NC.

Echinostelium apitectum K. D. Whitney

NC: JHK1442bMC (24), JHK1468aMC (34), on bark. New to NC.

Echinostelium arboreum H. W. Keller \& T. E. Brooks

NC: JHK689gMC (36), on bark from Olea paniculata R. Br. New to NC. 
Echinostelium coelocephalum T. E. Brooks \& H. W. Keller

NC: JHK878cMC (17), on Casuarina bark. New to NC.

Echinostelium colliculosum K. D. Whitney \& H. W. Keller

NC: JHK730MC (27), on bark. JHK731MC (30), on Nothofagus bark. New to NC.

Echinostelium corynophorum K. D. Whitney

NC: JHK737gMC (27), on bark. New to NC.

Echinostelium elachiston Alexop.

NC: JHK737eMC (27), on bark. New to NC

Echinostelium lunatum L. S. Olive \& Stoian.

NC: JHK693MC (36), on bark from Olea paniculata R. Br. New to NC

Echinostelium minutum de Bary

PNG: JHK773bMC (1), JHK808dMC (8), JHK810cMC (9), JHK821dMC (10), JHK833eMC (10), on bark. New to PNG.

NC: JHK175 (32), decaying wood. JHK729bMC (25), JHK730cMC (18), on bark.

JHK733MC (20), on Tieghemopanax bark. JHK735MC (19), on bark from Pinus caribea

Morelet. New to NC.

Echinostelium paucifilum K. D. Whitney

PNG: JHK773aMC (1), JHK808aMC (8), JHK810aMC (9), JHK821aMC (10), JHK833aMC (10), on bark. New to PNG.

NC: JHK729aMC (25), JHK730aMC (18), on bark. New to NC.

The determination of E. paucifilum was based on comparison with a slide of the species provided by Kenneth Whitney. Each of the bark samples that yielded E. paucifilum three days later also yielded E. minutum. In all the samples the latter species was approximately twice as large as the former and also had a more intricate capillitium.

Elaeomyxa cerifera (G. Lister) Hagelst.

PNG: JHK913bMC (8), on Nepenthes litter. New to PNG.

Elaeomyxa miyazakiensis (Emoto) Hagelst.

NC: JHK689eMC (36), on bark from Olea paniculata R. Br. New to NC.

This species has been rarely reported globally. Two sporocarps developed. Determination was made by M. L. Farr after comparison with herbarium material.

Enerthenema papillatum (Pers.) Rostaf.

NC: JHK174 (32), JHK177 (32), on decaying wood. New to NC.

Fuligo aurea (Penz.) Y. Yamam.

NC: JHK233 (41), several large fructifications $(\sim 20 \times 30 \mathrm{~cm})$ on sawdust. JHK276 (32), on decaying wood. New to NC.

Fuligo cinerea (Schwein.) Morgan

NC: JHK1466bMC (18), on tortoise dung. New to NC.

Fuligo megaspora Sturgis

NC: JHK1421 (26), on decaying plant litter. New to NC. 
Fuligo muscorum Alb. \& Schwein.

NC: JHK1473a (18), on decaying tree fern frond. New to NC.

Fuligo septica (L.) F. H. Wigg.

PNG: JHK2 (1), on decaying wood. Locals claimed it to be very common. New to PNG. NC: JHK251 (30), JHK267 (32), JHK392 (15), JHK393 (15), JHK394 (15), on decaying wood. EHS3371 (26), on a living Agatis sp. Huguenin and Kohler (1969) states that F. septica [as (L.) Weber] is common in NC and has been collected in Nouméa (no accession number given).

Hemitrichia calyculata (Speg.) M. L. Farr

PNG: JHK57 (3), JHK59 (3), JHK65 (3), JHK75b (3), JHK109 (6), JHK111a (6), JHK119 (6), JHK120 (8), JHK130 (8), on decaying wood. JHK76 (3), JHK77 (3), on compost. JHK117 (6), on the wooden frame of a bird cage. New to PNG.

NC: JHK162 (28), JHK179 (32), JHK186 (32), JHK218 (37), JHK255b (32), JHK270 (32), JHK279 (32), JHK330 (36), JHK341 (36), JHK343b (36), JHK358a (36), JHK375 (32), JHK385a (26), JHK386 (26), JHK400 (15), JHK401 (15), JHK402a (15), EHS3360 (23), EHS3367 (26), EHS3375 (29), EHS3404 (11), on decaying wood. New to NC.

Hemitrichia clavata (Pers.) Rostaf.

PNG: JHK56a (3), JHK59 (3), on decaying wood. New to PNG.

Hemitrichia serpula (Scop.) Rostaf. ex Lister PNG: JHK80 (4), JHK106 (6), on decaying wood. New to PNG.

NC: JHK157 (28), JHK257 (32), JHK259 (32), JHK268 (32), JHK381 (26), EHS3403 (11), decaying wood. NC67002 (18), on decaying wood of Cocos nucifera L. Huguenin and Kohler (1969) states that this species is very common in NC.

Kelleromyxa fimicola (Dearn. \& Bisby) Eliasson

NC: JHK1436MC (32), on cow dung. New to NC.

Lamproderma arcyrioides (Sommerf.) Rostaf.

NC: JHK1467bMC (24), on bark. New to NC.

Lamproderma columbinum (Per.) Rostaf.

NC: JHK1454bMC (18), on tortoise dung. New to NC.

Lamproderma muscorum (Lév.) Hagelst.

NC: EHS3414MC (31), on dead leaves. New to NC.

Lamproderma scintillans (Berk. \& Broome) Morgan

PNG: JHK55 (3), JHK56 (3), on charred wood. New to PNG.

Leocarpus fragilis (Dicks.) Rostaf.

NC: JHK1423 (17), on water logged decaying Dacrydium wood. New to NC.

Lepidoderma carestianum (Rabenh.) Rostaf.

NC: JHK802bMC (33), on Sapindaceae bark. New to NC.

Lepidoderma tigrinum (Schrad.) Rostaf.

NC: JHK899a (34), on decaying wood. New to NC. 


\section{Licea biforis Morgan}

PNG: JHK721MC (1), on Terminalia bark. New to PNG.

NC: JHK691MC (36), on bark from Olea paniculata R. Br. New to NC.

Licea floriformis T. N. Lakh. \& R. K. Chopra

PNG: JHK8aMC (1), on bark from Albizia saman F. Müll. New to PNG.

NC: JHK699bMC (21), on Casuarina bark. JHK786aMC (40), on litter from Parasitaxus usta (Vieill.) de Laub. New to NC.

Licea cf. hydrargyra Nann.-Bremek., T. N. Lakh. \& R. K. Chopra

PNG: JHK876cMC (1), on bark from Albizia saman F. Müll. New to PNG.

The sporocarps are typical according to the description as confirmed by N.E. NannengaBremekamp, but the spores are oval 8.5-10×13-15 $\mu \mathrm{m}$, smaller and more oval than in the description 12.5-13×14-15 $\mu \mathrm{m}$. This could, perhaps, be caused by unfavourable conditions during fruiting, but as the collection contained only two sporocarps it is at present impossible to draw further conclusions.

Licea kleistobolus G. W. Martin

NC: JHK730bMC (26), on bark. JHK888MC (18), on coconut husk. New to NC.

Licea marginata Nann.-Bremek.

PNG: JHK4MC (1), on tree fern rhizome. New to PNG.

NC: JHK788dMC (23), on Nothofagus bark. New to NC.

Licea operculata (Wingate) G. W. Martin

NC: JHK866MC (16), JHK903cMC (23), on bark. New to NC.

Licea parasitica (Zukal) G. W. Martin

NC: JHK698MC (36), on bark from Olea paniculata R. Br. New to NC.

Licea pedicellata (H. C. Gilbert) H. C. Gilbert

NC: JHK914MC (36), on bark. New to NC.

Licea cf. perexigua T. E. Brooks \& H. W. Keller

PNG: JHK720cMC (1), on bark. New to PNG.

The spores are too dark for a typical $L$. perexigua.

Licea pusilla Schrad.

NC: JHK906MC (22), on deer dung. New to NC.

Licea scyphoides T. E. Brooks \& H. W. Keller

PNG: JHK702MC (1), JHK706MC (10), on bark. New to PNG.

NC: JHK690MC (36), on bark from Olea paniculata R. Br. New to NC.

Licea testudinacea Nann.-Bremek.

NC: JHK879bMC (25), on Neocallitropsis bark. New to NC.

Lindbladia tubulina Fr.

NC: JHK344 (36), on decaying wood. New to NC.

Lycogala confusum Nann.-Bremek. ex Ing

NC: Lister (1922) reported this species as L. epidendrum var. tessellatum Lister 
Lycogala conicum Pers.

NC: JHK342 (36), JHK343a (36), on decaying wood. New to NC.

Lycogala epidendrum (L.) Fr.

PNG: JHK47 (2), on decaying wood. Reported from New Guinea by Berkeley (1842).

NC: EHS3361(23), EHS3386 (39), EHS3411 (11), EHS3364 (23), NC66180 (18) on

decaying wood. NC67028 (23), on a small tree. MNHN09.325 (18). Reported by Lister (1922) as “typical” L. epidendrum.

Persoon (1826) described L. marianna based on material collected in the Mariana Islands during the French expedition around the world 1817-1820. L. marianna is said to differ from L. epidendrum mainly in the orange colour of the spore mass. In the experience of H. Kylin, specimens of $L$. epidendrum with an orange tinge to the spore mass were common in PNG; $L$. marianna is likely synonymous with $L$. epidendrum.

Lycogala exiguum Morgan

NC: JHK227 (41), JHK300 (35), on decaying wood. JHK234 (41), on sawdust. New to NC.

Lycogala flavofuscum (Ehrenb.) Rostaf.

NC: JHK866 (33), JHK1474 (26), on decaying wood. New to NC.

Macbrideola argentea Nann.-Bremek. \& Y. Yamam.

NC: JHK748MC (37), on Metrosideros bark. JHK770MC (21), on bark of dead tree. New to NC.

Macbrideola decapillata H. C. Gilbert

NC: JHK1472MC (26), on bark. New to NC.

Macbrideola martinii (Alexop. \& Beneke) Alexop.

NC: JHK757aMC (15), on bark. New to NC.

Macbrideola scintillans H. C. Gilbert

NC: JHK1466aMC (17), on bark. New to NC.

Metatrichia floriformis (Schwein.) Nann.-Bremek.

NC: JHK1403a (26), on decaying wood. New to NC.

Metatrichia horrida Ing

NC: EHS3401 (11), on decaying wood. New to NC.

Metatrichia vesparia (Batsch) Nann.-Bremek. ex G. W. Martin \& Alexop.

NC: JHK1464 (21), on decaying wood. New to NC.

Minakatella longifila G. Lister

NC: JHK796bMC (27), JHK934MC (24) on bark. New to NC. Determination confirmed by M.L. Farr.

Mucilago crustacea F. H. Wigg.

NC: JHK288 (18), on dry grass. New to NC.

Paradiachea caespitosa (Sturgis) Hertel ex H. Neubert, Nowotny \& K. Baumann

PNG: Reported as Diachea caespitosa (Sturgis) Lister \& G. Lister by Farr (1979). 
Paradiacheopsis rigida (Brândză) Nann.-Bremek.

NC: JHK1454dMC (18), on tortoise dung. New to NC.

Perichaena chrysosperma (Curr.) Lister

PNG: JHK715MC (10), on bark. New to PNG.

NC: EHS3374 (29), on decaying wood. New to NC.

Perichaena corticalis (Batsch) Rostaf.

PNG: JHK723MC (10), on bark. New to PNG.

Perichaena depressa Lib.

NC: EHS3392 (13), on coconut palm fronds. EHS3388 (39), on decaying wood. New to NC.

Perichaena microspora Penz. \& A. Lister

NC: JHK1450 (17), on decaying wood. New to NC.

Perichaena syncarpon T. E. Brooks

NC: JHK1451MC (18), on tortoise dung. New to NC.

Physarella oblonga (Berk. \& M. A. Curtis) Morgan

NC: EHS3381 (29), on fresh tree stump. EHS3394 (12), on decaying wood. NC67038 (18), on decaying wood of coconut palm. MNHN09.331 (18). New to NC.

Physarum album (Bull.) Chevall

NC: JHK159 (28), JHK305 (35), JHK329 (36), JHK369 (18), JHK402b (15), JHK403 (15), JHK404 (15), EHS3363 (23), on decaying wood. MNHN09.334 (18). New to NC.

Physarum bethelii T. Macbr., ex G. Lister

NC: JHK348 (36), JHK391a (15), on decaying wood. New to NC.

Physarum bogoriense Racib.

PNG: One record on Elaeis guineensis Jacq. in Shaw (1984).

Physarum carneum G. Lister \& Sturgis

PNG: JHK861oMC (1), on termite nest material. New to PNG.

Physarum cinereum (Batsch) Pers.

PNG: PNG3460 (Popondetta), PNG3462 (Popondetta), PNG3984 (Markham Valley),

PNG6472, PNG6488, PNG6491 on various plants and litter (Shaw 1984).

Physarum citrinum Schumach.

NC: NC67027 (Col de la Pirogue), on the bark of a living tree.

Physarum compressum Alb. \& Schwein.

NC: EHS3421MC, on banana. New to NC.

Physarum contextum (Pers.) Pers.

NC: JHK1441MC (22), on deer dung. New to NC.

Physarum dictyospermun Lister \& G. Lister

NC: JHK1469aMC (21), on bark from dead tree. New to NC.

Two sporocarps developed in moist chamber determined by N.E. Nannenga-Bremekamp. 
Physarum echinosporum Lister

PNG: JHK700MC (1), on Mimosaceae bark. New to PNG.

Physarum globuliferum (Bull.) Pers.

NC: JHK307 (35), JHK318 (36), JHK380 (32), on decaying wood. New to NC.

Physarum gyrosum Rostaf.

NC: JHK1454kMC (18), on tortoise dung. New to NC.

Physarum javanicum Racib.

PNG: JHK861mMC (1), on termite nest material. New to PNG.

Physarum leucophaeum Fr.

NC: JHK1438eMC (26), on bark. New to NC.

Physarum leucopus Link

PNG: JHK890aMC (9), on Nepenthes litter. New to PNG.

Physarum melleum (Berk. \& Broome) Massee

PNG: PNG6850 (Boroka), on dead leaves. The specimen is atypical in that it contains almost no lime.

Physarum mutabile (Rostaf.) G. Lister

PNG: JHK861jMC (1), on termite nest material. New to PNG.

Physarum nicaraguense T. Macbr.

PNG: JHK861hMC (1), on termite nest material. New to PNG.

NC: JHK398 (15), JHK399 (15), on decaying wood. New to NC.

Physarum notabile T. Macbr.

NC: JHK911aMC (20), on Araucaria bark. New to NC.

Physarum cf. oblatum T. Macbr.

NC: JHK439 (26), on decaying wood. New to NC.

Physarum pezizoideum (Jungh.) Pavill. \& Lagarde

PNG: PNG4245 (Popondetta), on Leucaena leucocephala (Lam.) de Wit.

NC: JHK741MC (15), on bark. EHS3385 (39), on decaying coconut palm wood. New to NC.

Physarum polycephalum Schwein.

NC: JHK1457bMC (24), on bark. New to NC.

Physarum pusillum (Berk. \& M. A. Curtis) G. Lister

NC: JHK365 (18), JHK366 (18), on decaying wood. New to NC.

Physarum roseum Berk. \& Br.

PNG: JHK123 (8), JHK136 (9), on decaying wood. New to PNG.

NC: JHK391a (26), JHK402a (28), JHK404b (26), JHK406 (26), JHK407 (15), JHK408 (15), JHK408 (15), JHK409 (15), JHK410 (15), JHK411 (15), JHK412 (15), NC67039 (18), on decaying wood. Also in Lister (1922).The specimens JHK407-JHK412 were collected over an area of approximately $50 \times 70 \mathrm{~m}$ with an abundance of $P$. roseum on virtually all decaying 
wood. Many of the sporocarps have a hollow pseudocolumella formed by the peridium as described by Kylin and Mitchell (1987).

Physarum serpula Morgan

NC: EHS3400 (14), on dead Aloe sp. New to NC.

Physarum spectabile Nann.-Bremek., Lado \& G. Moreno

NC: EHS3397 (12), on freshly cut wood. New to NC.

Physarum stellatum (Massee) G. W. Martin

PNG: JHK133 (8), on living Araucaria. New to PNG.

Physarum straminipes Lister

NC: JHK1491bMC (19), on bark. New to NC.

Physarum sulphureum Alb. \& Schwein.

PNG: JHK861gMC (1), on termite nest material. New to PNG.

Physarum superbum Hagelst.

NC: EHS3402 (12), on freshly cut wood. EHS3412MC (12), on coconut frond. EHS3420MC (12), on wood. New to NC.

Physarum tenerum Rex

NC: JHK1418MC (17), on plant litter. New to NC.

Physarum viride (Bull.) Pers.

PNG: JHK90 (7), on recently felled Nothofagus. New to PNG.

NC: JHK160 (28), JHK197 (28), JHK304 (35), EHS3383 (38), EHS3369 (26), EHS3370

(26), on decaying wood. EHS3415MC (26), on wood. MNHN09.332 (18). Also reported (as P. viride var. aurantium (Bull.) Lister) by Lister (1922).

Protophysarum phloiogenum M. Blackw. \& Alexop.

NC: JHK903MC (17), on bark. New to NC. Determination by M. L. Farr.

Prototrichia metallica (Berk.) Massee

NC: JHK1436 (26), on decaying wood. New to NC.

Reticularia intermedia Nann.-Bremek.

NC: EHS3390 (13), EHS3378 (29), on decaying wood. New to NC.

Reticularia splendens Morgan

NC: JHK759 (26), JHK921 (31), on decaying wood. New to NC.

Stemonaria longa (Peck) Nann.-Bremek., R. Sharma \& Y. Yamam.

NC: EHS3417 (12), EHS3419 (38), on decaying wood. New to NC.

Stemonaria pilosa Nann.-Bremek.

NC: EHS3416 (29), on decaying wood. New to NC.

Stemonitopsis curiosa Nann.-Bremek. \& Y. Yamam.

NC: EHS3377 (29), on decaying wood. New to NC.

Stemonitopsis cf. hyperopta (Meyl.) Nann.-Bremek.

NC: MNHN09328 (18). New to NC. 
Stemonitopsis microspora (Lister) Nann.-Bremek.

PNG: JHK62 (3), on decaying wood. New to PNG.

Stemonitopsis typhina (F. H. Wigg.) Nann.-Bremek.

NC: JHK291 (31), EHS3380 (29), EHS3393 (12), on decaying wood. Reported by Lister (1922) as Comatricha typhoides (Bull.) Rostaf. New to NC.

Stemonitis axifera (Bull.) T. Macbr.

PNG: JHK63 (3), on decaying wood. PNG7598 (Kerawat, New Britain), on grass. Reported as $S$. ferruginea Ehrenb. by Schumann and Lauterbach (1901).

NC: JHK164 (28), JHK179 (32), JHK182 (32), JHK200 (28), JHK308 (35), EHS3382 (38), on decaying wood. Reported as S. ferruginea Ehrenb. var. violacea Meylan by Lister (1922).

Stemonitis flavogenita E. Jahn.

NC: NC68028 (17), on dead branch of Casuarina deplancheana Miq.

Stemonitis fusca Roth

PNG: JHK704MC (1), on Dacrydium bark. Reported from Strickland River by Cooke (1886).

NC: JHK171 (32), JHK319 (36), JHK347 (36), JHK360 (18), JHK444 (25), EHS3405 (11), on decaying wood. NC67007 (18), on wood chips of Cocos nucifera L., NC63123 (Port Laguerre), on the trunk of an old Cassia alata L.

Stemonitis herbatica Peck

PNG: One record on Elaeis guineensis Jacq. (Shaw 1984).

Stemonitis pallida Wingate

NC: NC67001 (18), on wood chips of Cocos nucifera L.

Stemonitis splendens Rostaf.

PNG: JHK81 (4), JHK94 (7), JHK113 (6), on decaying wood. PNG5059 (Hombrum Bluff), on wooden beams indoors. PNG10243, in wooden cupboard.

NC: JHK205 (23), JHK228 (41), JHK235 (41), JHK256 (32), JHK290 (31), JHK329 (36), JHK345 (36), JHK349 (36), JHK357 (36), JHK377 (32), EHS3366 (26), on decaying wood. NC67025 (Col de la Pirogue). "Common on bark of living trees in humid forests” (Huguenin and Kohler 1969). Also reported by Lister (1922).

Symphytocarpus flaccidus (Lister) Ing \& Nann.-Bremek.

PNG: JHK863 (6), on decaying wood. New to PNG.

Trichia affinis de Bary

NC: 161 (28), JHK173 (28), JHK196 (28), JHK217 (37), JHK219 (37), JHK220 (37),

JHK258 (32), JHK260 (32), JHK346 (36), on decaying wood. JHK236 (41), on sawdust. New to NC.

Trichia decipiens (Pers.) T. Macbr.

NC: JHK271 (32), on decaying wood. New to NC.

Trichia erecta Rex

NC: JHK1452MC (18), on tortoise dung. New to NC. 
Trichia favoginea (Batsch) Pers.

PNG: JHK51a (2), on decaying wood. New to PNG.

Trichia persimilis P. Karst.

NC: JHK226 (41), EHS3396 (12), NC66181 (Col de la Pirogue), on decaying wood.

Trichia scabra Rostaf.

NC: JHK1463b (26), on decaying leaves. New to NC.

Trichia varia (Pers. ex J. F. Gmel.) Pers.

NC: NC67125 (18), on decaying wood.

Trichia verrucosa Berk.

NC: JHK435 (27), on decaying wood. New to NC.

Tubifera ferruginosa (Batsch) J. F. Gmel.

NC: JHK344 (36), NC67009 (17), on decaying wood.

Willkommlangea reticulata (Alb. \& Schwein.) Kuntze

NC: JHK867MC (34), on bark. New to NC.

\section{Ecological notes}

A surprising number of myxomycete species developed in moist chamber cultures of Olea bark, Parasitaxus litter, tortoise dung, and termite nest material. However, this may be an effect of the amount of effort spent on these substrates. In our experience, Olea bark from the Mediterranean often yields many myxomycete species, and under the. Under the assumption that bark from any Olea species should yield many myxomycete species, and because no other accounts of myxomycetes from Parasitaxus litter, tortoise dung, or termite nest material, much effort was spent on moist chamber cultures of these substrates. The number of species reported from these substrates may, therefore, be an effect of the time spent on these substrates rather than that they are particularly rich in myxomycetes.

On 8 December 1983, a bright yellow phaneroplasmodium was observed on decaying drift wood at Plage de Ouroué (location 33). The plasmodium was fully exposed to the midday sun; the wood kept damp by sea spray. Parts of the plasmodium were collected, but could not be brought to fruit. The occurrence of the plasmodium indicated a surprising salt tolerance in an organism group that had previously not been known to be adapted to the marine environment. However, recently endocommensalic amoebae closely affiliated with the myxomycete genus Didymium (identified with genetic markers) have been isolated from the body cavity of sea urchins (Dyková et al. 2007). It would therefore seem that, although no fruiting bodies have as yet been reported from the marine environment, mycetozoa as such, may not be restricted to terrestrial ecosystems.

\section{Acknowledgments}

M. Beauvallett, H. Bouwman, R. Cook, M. Ducousso, G. Eyssartier, M. L. Farr, E. E. Henty, V. Hofstetter, B. Ing, J.T. Johansson, H. W. Keller, F. Ljungqvist, P. P. Lowry II, G. 
McPherson, M. Meyer, P. Morat, N. E. Nannenga-Bremekamp, L. S. Olive, J. Rammeloo, M. Roos, D. Shaw, L. Thien, and K. D. Whitney, were helpful with either the fieldwork, determination of difficult specimens, literature references, herbarium specimens, or preparation of the manuscript. Two anonymous reviewers improved the manuscript. The national and provincial authorities of the respective provinces are thanked for collection permits. Partial funding was provided to H. Kylin by the Botanical Society of Lund (the Svante Murbeck Fund), and the Natural Science Society at Stockholm University.

\section{References}

Allison A (2009) New Guinea biology. In: Gillespie RG, Clague DA (eds) Encyclopedia of islands. University of California Press, Berkeley, pp 652-659

Berkeley ML (1842) Description of fungi collected by R. B. Hinds, Esq., principally in the islands of the Pacific. Hooker's J Bot 1:447-457

Buyck B (1982) The genus Diderma Persoon (Myxomycetes) in Belgium. Bull Jard bot natl Belg, 52:165-209

Cooke MC (1886) Fungi of New Guinea. Grevillea 14:115-118

Davies HL (2009) New Guinea geology. In: Gillespie RG, Clague DA (eds) Encyclopedia of islands. University of California Press, Berkeley, pp 659-665

Dyková I, Lom J, Dvořaková H, Pecková H, Fiala I (2007) Didymium-like myxogastrids (class Mycetozoa) as endocommensals of sea urchins (Sphaerechinus granularis). Folia Parasitol 54:1-12

Farr ML (1979) Notes on myxomycetes II. New taxa and records. Nova Hedw 31:103-118

Fiore-Donno AM, Nikolaev SI, Nelson M, Pawlowski J, Cavalier-Smith T. Baldauf SL (2010) Deep Phylogeny and Evolution of Slime Moulds (Mycetozoa). Protist 161:55-70

Huguenin B, Kohler F (1969) Quelques myxomycètes de Nouvelle-Calédonie. Bull Soc Mycol Fr 85:381-383, plates I + II

Kylin JH, Mitchell DW (1987) Contributions to the myxomycete flora of Fiji and Western Samoa. Nova Hedw 45:375-381

Lado C (2005-2012) An on line nomenclatural information system of Eumycetozoa. . http://www.nomen.eumycetozoa.com. Accessed 20 April 2012

Lister G (1922) Mycetozoa. J Linn Soc Lond, Bot 46:94-96

Macbride TH (1926) A bit of Polynesian mycology. Mycologia 18:125-131

Mitchell DW (1980) A key to the corticolous myxomycetes. First edn. British Mycological Society, London

Mitchell DW (1992) The myxomycota of New Zealand and its island territories. Nova Hedw 55:231-256 
Murienne J (2009) New Caledonia biology. In: Gillespie RG, Clague DA (eds) Encyclopedia of islands. University of Califormia Press, Berkeley, pp 643-645

Nannenga-Bremekamp NE (1991) A guide to temperate myxomycetes. Biopress, Bristol

Persoon CH (1826) Lycogala marianna. In: Gaudichaud C: Voyage de l'Uranie et la Physicienne. Chez Pillet Ainé, Paris, pp 179-180

Rawling TJ (2009) New Caledonia geology. In: Gillespie RG, Clague DA (eds) Encyclopedia of islands. University of California Press, Berkeley, pp 645-648

Schumann KM, Lauterbach K (1901) Die Flora der deutschen Schutzgebiete in der Südsee. Verlag von Gebrüder Bornträger, Leipzig

Shaw DE (1984) Microorganisms in Papua New Guinea. Research Bulletin No. 33. Department of Primary Industry, Port Moresby

Stephenson SL (2003) Myxomycetes of New Zealand, vol Volume 3. The Fungi of New Zealand. Fungal Diversity Press, Hong Kong

Stephenson SL, Novozhilov YK, Shirley C, Mitchell DW (2009) Additions to the myxomycetes known from New Zealand, including a new species of Diderma. Aust Syst Bot 22:466-472.

Sydow H, Sydow P (1916) Fungi Papuani. In: Lauterbach, C.: Beiträge zur Flora von Papuasien V. Bot Jahrb 54:246-261

UARK (2012) Ceratiomyxa morchella. http://www.discoverlife.org/mp/20l?id=UARK22085. Accessed 24 February 2012 